\title{
TRIM24 Gene
}

National Cancer Institute

\section{Source}

National Cancer Institute. TRIM24 Gene. NCI Thesaurus. Code C95280.

This gene plays a role in hormone-dependent gene transcription. 